\title{
POTENSI HUKUM ADAT: \\ PERAN MAJELIS DESA PAKRAMAN (MDP ) BALI \\ DALAM PEMBANGUNAN HUKUM NASIONAL
}

\author{
Oleh: \\ Anak Agung Istri Ari Atu Dewi ${ }^{1}$ \\ Fakultas Hukum Universitas Udayana
}

\begin{abstract}
Abstrak
Penelitian ini bertujuan untuk mengetahui dan menganalisa tentang Potensi Hukum Adat Bali dalam Pelaksanaan Pembangunan Hukum Nasional dan kedudukan dan fungsi Majelis Desa Pakraman (MDP) Di Provinsi Bali Dalam Pembangunan Hukum Nasional

Penelitian ini merupakan penelitian Socio-legal dengan menggunakan perangkat analisis hukum berupa hermeneutika hukum dan dianalisis melalui teori pluralisme hukum, teori sistem hukum serta teori pembangunan hukum.

Berdasarkan hasil penelitian, diketahui bahwa Majelis Desa Pakraman Bali dalam pembangunan hukum nasionalberkedudukan sebagai lembaga independen dan/atau berada di luar sistem Pemerintah Daerah Provinsi Bali yang berfungsi untuk melakukan koordinasi baik dengan pemerintah maupun desa pakraman dalam rangka melakukan penguatan, pemberdayaan dan pembinaan hukum adat dan budaya Bali.

Apabila dikaitkan dengan proses pembentukan produk hukum, baik itu produk hukum nasional maupun produk hukum daerah, kedudukan dan fungsi MDP adalah sebagai masyarakat yang berfungsi untuk memberikan masukan baik secara tertulis maupun lisan dalam proses pembentukan produk hukum sebagaimana amanat Pasal 96 ayat (1) UU 12 Tahun 2011 tentang Pembentukan peraturan perundang-undangan. Secara sosiologis MDP senantiasa dilibatkan dalam proses pembahasan Rancangan Peraturan Perundang-undangan dan Rancangan Peraturan daerah. Selanjutnya dalam konteks penyelesaian kasus adat, kedudukan dan fungsi MDP Bali adalah: pertama, berkedudukan sebagai Sabha Kerta (Hakim Perdamain Desa) yang berfungsi memutus kasus adat dengan tatacara dan mekanisme yang telah ditentukan. Kedua, MDP berkedudukan sebagai mediator (penengah) dan berfungsi untuk mendamaikan para pihak yang bersengketa. Dengan menganalisis potensi hukum adat Bali, kedudukan dan fungsi MDP maka memberi arah pada peran MDP Bali dalam pembangunan Hukum Nasional.
\end{abstract}

Kata kunci: Pembagunan Hukum Nasional, Majelis Desa Pakaraman, Bali.

\section{Abstract}

This study aims to determine and analyze the potential of Balinese Customary Law in the implementation of national law as well as the position and function of the Majelis Desa Pakraman (Customary Village Assembly) of Bali Province in the development of national law.

This is a socio-legal study that employs legal hermeneutics as its legal analysis tool and then analyzed by legal pluralism theory, legal system theory and legal development theory.

Based on this research, it is noted that the Assembly of the Customary Villagein Bali, in the development of national law, serves as an independent institution and/or outside the system of the Provincial Government of Bali. It serves to coordinate both with the government and desa pakraman (customary village) in order to strengthen, empower and develop the Balinese customary law and culture.

When the above discussion is linked with process of legal product formation, both national lawsandproducts of local regulation, The position and function of MDP are as community that serves to provide feedback either in writing or orally in the process of establishing laws as mandated by Article 96 paragraph (1) of Act No. 12 of 2011 on the Establishment of the Laws and Regulations. Sociologically MDP always be involved in discussing the draft of Laws and Regulations as well as the draft of Regional Regulation. Furthermore, in the context of settlement of customary cases, the position and function of MDP Bali are: first, serves as Kerta Sabha (The village peacekeeping Judge) that decides the customary cases with the procedures and mechanisms that have been determined. Second, MDP serves as a mediator and therefore it reconciles the conflicting parties. By analyzing the potential of Balinese customary law, the position and function of MDP thus those leadto the role of MDP in the development of national law.

Keywords: National Law Development, Majelis Desa Pekraman (Customary Village Assembly), Bali. \footnotetext{
Udayana.

${ }^{1}$ Anak Agung Istri Ari Atu Dewi adalah dosen pada Bagian Hukum dan Masyarakat Fakultas Hukum Universitas
} 


\section{Kertha Patrika}

KERTHA PATRIKA

Volume 38, Nomor 3, Desember 2016

\section{PENDAHULUAN}

\subsection{Latar Belakang}

Pembangunan sistem hukum nasional selama ini dikualifisir dalam sejumlah dimensi, misalnya Pembangunan "perangkat hukum nasional", Pembangunan "tatanan hukum nasional", dan Pembangunan "budaya hukum nasional". ${ }^{2}$ Paradigma pembangunan hukum yang dianut oleh pemerintah pada kurun waktu lebih dari tiga dasa warsa terakhir ini cenderung memiliki sifat sentralisme hukum (legal centralism), melalui implementasi politik unifikasi dan kodifikasi hukum bagi seluruh rakyat dalam teritori Negara (rule-centered paradigm). ${ }^{3}$ Lebih lanjut, Nurjaya menyebutkan implikasi dari paradigma ini adalah hukum negara cenderung menggusur, mengabaikan, dan mendominasi keberadaan sistemsistem hukum yang lain, karena secara sadar hukum difungsikan sebagai governmental social control, atau sebagai the servant of repressive power, atau sebagai the command of a sovereign backed by sanction. ${ }^{4}$ Sejumlah pihak kemudian menawarkan berbagai pendekatan sebagai solusi atas kenyataan yang dihadapi ini, termasuk di antaranya munculnya konsep pembangunan hukum berbasis kearifan lokal yang menyertakan peran masyarakat adat dan hukum adat sebagai komponennya. ${ }^{5}$ Secara turun termurun, desa pakraman merupakan lembaga adat yang menjaga tradisi dan budaya masyarakat Bali dalam lingkup masing-masing desa secara otonom. Sebagai karakter desa yang otonom yang dapat mengelola dan mendayagunakan desa pakramannya sendiri (self regulations), sehingga menimbulkan suatu tafsir yang berbeda diantara desa pakramanitu sendiri. Sebagai contoh, dalam penerapan sanksi adat kasepekang ${ }^{6}$ kepada warganya (kramanya) yang berbeda.

Perihalpenerapan sanksi adat kasepekang, terjadi suatu perbedaan tafsir di desa pakraman terkait penerapan sanksi adat dimaksud. Atas Dasar tersebut dan untuk kesatuan tafsir terkait hukum adat dan budaya Bali maka Pemerintah Provinsi Bali membentuk Majelis Desa Pakraman (selanjutnya disebut MDP) dengan mendasarkan pada Peraturan Daerah Provinsi Bali Nomor 3 Tahun 2001 tentang Desa Pakraman(selanjutnya disebut Perda 3 Tahun 2001). Hal ini dapat dipahami bahwaterbentuknya MDP karena ada perintah dari Perda 3 Tahun 2001tentang Desa Pakraman.

Dalam peraturan daerah tersebut dinyatakan bahwa salah satu fungsi MDPmemberikan saran, usul dan pendapat kepada berbagai pihak baik perorangan, kelompok/lembaga termasuk pemerintah tentang masalah-masalah adat. ${ }^{7}$ Di sini dapat kita pahami bahwa MDP ini dapat menjadi sebuah lembaga (institusi) yang merepresentasikan kepentingan masyarakat adat di Bali untuk mengetengahkan berbagai isu dan masalah adat kepada pemerintah, termasuk di bidang hukum. Oleh karena itu perlu ada pengkajian lebih lanjut terkait dengan potensi hukum adat dan peran MDP yang fokus mengenai kedudukan dan fungsi MDP desa pakraman.

2 Pembangunan Sistem Hukum NasionalIndonesia, https://bardanawawi.wordpress.com/2009/12/24/38/.

3 I Nyoman Nurjaya, Memahami Kedudukan dan Kapasitas Hukum Adat Dalam Politik Pembangunan Hukum Nasional, Perspektif, 2011,Vol. XVI No. 4, h.241.

4 Ibid.

5 Hendra Wahanu Prabandani, Pembangunan Hukum BerbasisKearifan Lokal, http://birohukum.bappenas.go.id/data/data artikel_jdih/PEMBANGUNAN\%20HUKUM\%20BERBASIS\%20KEARIFAN\%20LOKAL.pdf

6 Dapat dipahami sanksi adat Kasepekang (dikucilkan) adalah salah satu sanksi yang dikenal dalam hukm adat bali karena warga desa adat melanggar ketentuan hukum adat (awig-awig desa adat)

7 Pasal 16 (1) (b) Peraturan Daerah Provinsi Bali Nomor 3 Tahun 2001tentang Desa Pakraman, Lembaran Daerah Provinsi Bali Tahun 2001 Nomor 29. 
KERTHA PATRIKA

Volume 38, Nomor 3, Desember 2016

\section{HASIL DAN PEMBAHASAN}

\subsection{POTENSI HUKUM ADAT BALI DALAM PELAKSANAAN PEMBANGUNAN HUKUM}

\subsubsection{Hukum Adat Bali dalam kerangka pluralisme hukum}

Hukum adat Bali merupakan hukum asli bangsa Indonesia yang mengandung unsur-unsur tradisi dan agama. Hukum adat Bali yang tumbuh dan berkembang dalam kesatuan masyarakat adat di Bali berfungsi sebagai pengatur dan pengendali prilaku warga masyarakat. Menurut Koesnoe, ${ }^{9}$ hukum adat merupakan model hukum yang lain dari pada model hukum yang ada di dunia. Hal ini dapat diartikan bahwa ada sistem hukum lain yang berlaku dalam kehidupan bermasyarakat selain hukum negara, yaitu hukum adat. Dalam konteks pluralisme hukum, hukum adat berada diluar dari sistem hukum negara, namun berlaku di dalamkehidupan masyarakat Indonesia. Berdasarkan urian di atas, pluralisme hukum pada intinya mengakui adanya lebih dari satu sistem hukum yang berlaku bagi masyarakat Indonesia. Sistem hukum tersebut adalah sistem hukum negara, sistem hukum adat dan sistem hukum agama. Dalam kajian ini relevansi pluralisme hukum adalah menempatkan sistem hukum adat dalam konteks ini adalah nilai-nilai hukum adat dan kearifan lokal dalam sistem hukum negara. Hal ini dapat dipahami bahwa nilai hukum adat dan kearifan lokal (temasuk karakterisktik hukum adat) dapat didayagunakan untuk pembangunan hukum nasional.

Eugen Ehrlich berpendapat bahwa hukum merupakan norma-norma sosial aktual yang mengatur semua aspek kemasyarakatan yang olehnya disebut dengan hukum yang hidup (living law). ${ }^{10}$ Hukum yang hidup (living law) adalah hukum yang dilaksanakan dalam masyarakat dan hukum hanya dapat dipahami dalam fungsinya di masyarakat. Hukum yang dilaksanakan dalam masyarakat dapat diklasifikasikan dengan adat, kebiasaan dan hukum adat. Pendapat Eugen Ehrlich ini mengandung arti bahwa hukum itu tumbuh dan berkembang dalam kehidupan masyarakat dan hukum tunduk pada kekuatan sosial tertentu dalam masyarakat.

Pandangan Eugen Ehrlich ini termasuk menentang aliran positivisme hukum yang menganggap hukum adalah undang-undang. Lebih lanjut dikatakan bahwa ada suatu hukum yang menguasai masyarakat sebagai suatu tata tertib perdamaian dan hukum ini juga digunakan sebagai dasar untuk melakukan segala aturan hukum dalam masyarakat. Sehingga dapat dikatakan bahwa hukum tidak harus dicari dan dijumpai dalam peraturan perundang-undangan melainkan dapat dijumpai dan dicari dalam masyarakat (hukum adat) itu sendiri.

Eugen Ehrlich juga memandang bahwa perlindungan negara melalui alat-alat pemaksa yang bersifat khusus tidak pernah penting walaupun telah ditetapkan. Lembaga hukum yang esensial adalah selalu didasarkan pada fakta-fakta hukum yang menekankan seluruh hukum pada kebiasaan, kekuasaan, kepemilikan dan pernyataan-pernyataan kehendak. Karena itu, ketaatan terhadap hukum adalah bukan kerena adanya norma-norma hukum yang memaksa tapi karena adanya paksaan sosial. ${ }^{11}$

9 H. Moh. Koesnoe. 1992. Hukum Adat sebagai suatu Model Hukum. Bandung: Penerbit Bandar Maju, h.4 (Selanjutnya disebut Moh Koesno I).

10 HR. Otje Salman dan Anthon F. Susanto. 2004. Beberapa Aspek Sosiologi Hukum. Bandung: Penerbit Alumni, h. 38.

11 Otje Salman Soemadiningrat. 2002. Rekonseptualisasi Hukum Adat Kontenporer. Bandung: Penerbit Alumni, h. 6. 
KERTHA PATRIKA

Volume 38, Nomor 3, Desember 2016

\begin{tabular}{|c|c|c|}
\hline $\begin{array}{l}\text { UU No. } 23 \text { Tahun } 2009 \\
\text { tentang PPLH }\end{array}$ & $\begin{array}{l}\text { Pasal } 1 \text { ayat (30) } \\
\text { upaya perlindungan dan pengelo- } \\
\text { laan lingkungan hidup harus me- } \\
\text { merhatikan nilai-nilai luhur yang } \\
\text { berlaku dalam tata kehidupan } \\
\text { masyarakat. }\end{array}$ & $\begin{array}{l}\text { Ada dasar pengakuan hukum } \\
\text { adat }\end{array}$ \\
\hline $\begin{array}{l}\text { UU No. } 6 \text { Tahun } 2014 \text { ten- } \\
\text { tang Desa }\end{array}$ & $\begin{array}{l}\text { BAB XIII } \\
\text { KETENTUAN KHUSUS DESA } \\
\text { ADAT } \\
\text { Pasal 96-Pasal } 111 \\
\text { Mengatur terkait dengan potensi } \\
\text { hukum adat }\end{array}$ & $\begin{array}{l}\text { Ada dasar pengakuan hukum } \\
\text { adat }\end{array}$ \\
\hline \multirow[t]{2}{*}{ UU Nomor 12Tahun 2011} & $\begin{array}{l}\text { Dalam Pasal } 96 \\
\text { (1) Masyarakat berhak memberi- } \\
\text { kan masukan secara lisan dan/ } \\
\text { atau tertulis dalam Pemben- } \\
\text { tukan Peraturan Perundang- } \\
\text { undangan. } \\
\text { (2) ... } \\
\text { (3) Masyarakat sebagaimana } \\
\text { dimaksud pada ayat (1) ada- } \\
\text { lah orang perseorangan atau } \\
\text { kelompok orang yang mem- } \\
\text { punyai kepentingan atas sub- } \\
\text { stansi Rancangan Peraturan } \\
\text { Perundang-undangan. } \\
\text { (4) ... }\end{array}$ & $\begin{array}{l}\text { Diatur partisipasi masyarakat da- } \\
\text { lam pembentukan peraturan pe- } \\
\text { rundang-undangan. } \\
\text { Ada dasar pengakuna hukum } \\
\text { adat. }\end{array}$ \\
\hline & $\begin{array}{l}\text { Diatur partisipasi masyarakat da- } \\
\text { lam pembentukan peraturan pe- } \\
\text { rundang-undangan. Ada dasar pen- } \\
\text { gakuna hukum adat. }\end{array}$ & $\begin{array}{l}\text { yang dimaksud masyarakat da- } \\
\text { lam Pasal } 96 \text { adalah termasuk } \\
\text { masyarakat adat dalam konteks } \\
\text { ini desa pakaman }\end{array}$ \\
\hline
\end{tabular}

Dalam tataran lokal di Provinsi Bali, potensi hukum adat juga diatur dalam Peraturan Daerah. Hal yang dimaksud digambarkan dalam table berikut:

Tabel 2 : Potensi Hukum Adat

\begin{tabular}{|l|l|l|}
\hline Peraturan Daerah Provinsi & Pasal 1 angka 25. Kearifan lokal ada- & Ada dasar berlakunya hukum \\
Bali Nomor 3 Tahun 2013 & lah nilai-nilai yang dikembangkan \\
Tentang Perlindungan Buah & adat digunakan oleh masyarakat Bali \\
Lokal & $\begin{array}{l}\text { dalam kehidupan dan lingkungan- } \\
\text { nya yang menyatu dengan sistem ke- } \\
\text { percayaan, adat istiadat, norma, dan } \\
\text { budaya, diekspresikan di dalam tra- } \\
\text { disi yang dianut dalam jangka waktu } \\
\text { yang lama. }\end{array}$ & \\
\hline
\end{tabular}




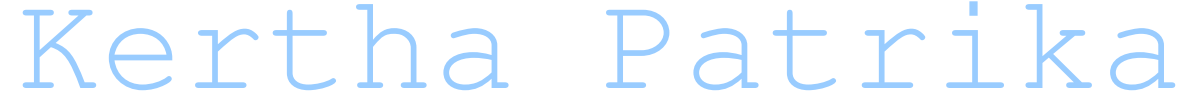

Potensi Hukum Adat: Peran Majelis Desa Pakraman (Mdp ) Bali Dalam Pembangunan Hukum Nasional Anak Agung Istri Ari Atu Dewi

\begin{tabular}{|c|c|c|}
\hline $\begin{array}{l}\text { Peraturan Daerah Provinsi } \\
\text { Bali Nomor } 3 \text { Tahun } 2001 \text {. }\end{array}$ & $\begin{array}{l}\text { Pasal } 5 \text { huruf d } \\
\text { Bersama-sama pemerintah melak- } \\
\text { sanakan pembangunan di segala } \\
\text { bidang terutama berkaitan dengan } \\
\text { keagamaan, kebudayaan, dan ke- } \\
\text { masyarakatan. } \\
\text { Pasal } 6 \text { huruf b } \\
\text { Turut serta menentukan setiap kepu- } \\
\text { tusan dalam pelaksanaan pemban- } \\
\text { gunan yang ada di wilayahnya teru- } \\
\text { tama yang beraitan dengan Tri Hita } \\
\text { Karana. }\end{array}$ & $\begin{array}{l}\text { Ada dasar berlakunya hukum } \\
\text { adat }\end{array}$ \\
\hline $\begin{array}{l}\text { Peraturan Daerah Provinsi } \\
\text { Bali Nomor } 16 \text { Tahun } 2009 \\
\text { Tentang Rencana Tata Ruang } \\
\text { Wilayah Provinsi Bali Tahun } \\
\text { 2009-2029 }\end{array}$ & $\begin{array}{l}\text { Pasal } 121 \\
\text { Arahan peraturan zonasi kawasan } \\
\text { peruntukan perikanan mencakup: } \\
\text {... } \\
\text { g. penerapan sanksi administrasi dan } \\
\text { sanksi adat terhadap pelaku penagka- } \\
\text { pan ikan. } \\
\text { Pasal 151 } \\
\text { Ayat (6) huruf d menyatakan Ka- } \\
\text { wasan konservasi pesisir dan pulau- } \\
\text { pulau kecil ditetapkan dengan cri- } \\
\text { teria yang mempunyai aturan lokal/ } \\
\text { kesepakatan adat masyarakat yang } \\
\text { diberlakukan untuk menjaga keles- } \\
\text { tarian lingkungan }\end{array}$ & $\begin{array}{l}\text { Ada dasar berlakunya hukum } \\
\text { adat }\end{array}$ \\
\hline $\begin{array}{l}\text { Peraturan Daerah Provinsi } \\
\text { Bali Nomor } 9 \text { Tahun } 2012 \\
\text { Tentang Subak }\end{array}$ & $\begin{array}{l}\text { Konsidran menimbang: } \\
\text { bahwa untuk melestarikan Lembaga } \\
\text { Subak berdasarkan falsafah Tri Hita } \\
\text { Karana sebagai organisasi sosial da- } \\
\text { lam bidang pertanian yang bersum- } \\
\text { ber pada ajaran agama Hindu di Bali } \\
\text { maka kedudukan, fungsi dan per- } \\
\text { anannya perlu diatur dengan Pera- } \\
\text { turan Daerah. }\end{array}$ & $\begin{array}{l}\text { Ada dasar berlakunya hukum } \\
\text { adat }\end{array}$ \\
\hline $\begin{array}{l}\text { Peraturan Daerah Provinsi } \\
\text { Bali Nomor } 4 \text { Tahun } 2012 \\
\text { Tentang Perubahan Ked- } \\
\text { ua Atas Peraturan Daerah } \\
\text { Provinsi Bali Nomor } 8 \text { Ta- } \\
\text { hun } 2002 \text { Tentang Lembaga } \\
\text { Perkreditan Desa }\end{array}$ & $\begin{array}{l}\text { Pasal } 1 \text { angka } 6 \\
\text { Desa Pakraman adalah kesatuan } \\
\text { masyarakat hukum adat di Provinsi } \\
\text { Bali yang mempunyai satu kesatu- } \\
\text { an tradisi dan tata krama pergaulan } \\
\text { hidup masyarakat umat Hindu secara } \\
\text { turun temurun dalam ikatan Kahyan- } \\
\text { gan Tiga atau Kahyangan Desa yang } \\
\text { mempunyai wilayah tertentu dan } \\
\text { harta kekayaan sendiri serta berhak } \\
\text { mengurus rumah tangganya sendiri. }\end{array}$ & $\begin{array}{l}\text { Ada dasar berlakunya hukum } \\
\text { adat }\end{array}$ \\
\hline
\end{tabular}




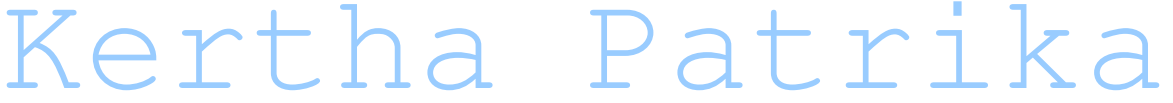

Potensi Hukum Adat: Peran Majelis Desa Pakraman (Mdp ) Bali Dalam Pembangunan Hukum Nasional Anak Agung Istri Ari Atu Dewi

membantu penyuratan awig-awig dan e) melaksanakan penyuluhan adat-istiadat secara menyeluruh. Ketentuan sebagaimana diatur di dalam AD/ART telah sesuai dengan Pasal 16 ayat (1) Perda Nomor 3 Tahun 2001 tentang Desa Pakraman.

Terdapat 1488 desa pakraman yang berada dalam wadah MDP Bali. Untuk lebih jelasnya dapat disimak dalam tabel berikut

Tabel 3 : Data jumlah Desa Pakraman Kabupaten / Kota Se Bali Tahun 2000-2015

\begin{tabular}{|l|l|c|c|c|c|c|c|c|c|c|c|c|c|c|c|c|c|}
\hline NO & KAB/KOTA & 2000 & 2001 & 2002 & 2003 & 2004 & 2005 & 2006 & 2007 & 2008 & 2009 & 2010 & 2011 & 2012 & 2013 & 2014 & 2015 \\
\hline 1 & Buleleng & 160 & 160 & 166 & 166 & 166 & 166 & 166 & 166 & 166 & 166 & 168 & 170 & 170 & 170 & 170 & 170 \\
\hline 2 & Jembrana & 59 & 59 & 63 & 63 & 63 & 63 & 64 & 64 & 64 & 64 & 64 & 64 & 64 & 64 & 64 & 64 \\
\hline 3 & Tabanan & 325 & 325 & 333 & 333 & 339 & 340 & 340 & 345 & 345 & 345 & 345 & 346 & 346 & 348 & 348 & 348 \\
\hline 4 & Badung & 119 & 119 & 119 & 119 & 119 & 120 & 120 & 120 & 120 & 120 & 122 & 122 & 122 & 122 & 122 & 122 \\
\hline 5 & Denpasar & 35 & 35 & 35 & 35 & 35 & 35 & 35 & 35 & 35 & 35 & 35 & 35 & 35 & 35 & 35 & 35 \\
\hline 6 & Gianyar & 260 & 260 & 261 & 266 & 266 & 268 & 269 & 271 & 271 & 271 & 271 & 272 & 272 & 272 & 272 & 272 \\
\hline 7 & Bangli & 152 & 153 & 153 & 153 & 155 & 155 & 155 & 158 & 158 & 158 & 168 & 168 & 168 & 168 & 168 & 168 \\
\hline 8 & Klungkung & 86 & 86 & 89 & 89 & 92 & 92 & 96 & 106 & 106 & 106 & 108 & 113 & 113 & 119 & 119 & 119 \\
\hline 9 & Karangasem & 180 & 180 & 180 & 180 & 185 & 185 & 188 & 188 & 188 & 188 & 190 & 190 & 190 & 190 & 190 & 190 \\
\hline & JUMLAH & $\mathbf{1 3 7 6}$ & $\mathbf{1 3 7 7}$ & $\mathbf{1 3 9 9}$ & $\mathbf{1 4 0 4}$ & $\mathbf{1 4 2 0}$ & $\mathbf{1 4 2 4}$ & $\mathbf{1 4 3 3}$ & $\mathbf{1 4 5 3}$ & $\mathbf{1 4 5 3}$ & $\mathbf{1 4 5 3}$ & $\mathbf{1 4 7 1}$ & $\mathbf{1 4 8 0}$ & $\mathbf{1 4 8 0}$ & $\mathbf{1 4 8 8}$ & $\mathbf{1 4 8 8}$ & $\mathbf{1 4 8 8}$ \\
\hline
\end{tabular}

Sumber : MDP Bali

Berdasarkan wawancara yang telah dilakukan pada tanggal 20 November 2015 dengan P Windia seorang Nayaka di MUDP Provinsi Bali, dinyatakan bahwa MUDP berperan dalam pembangunan hukum nasional. Mendasarkan pada teori sistem hukum khususnya struktur hukum, bahwa MDP Bali menjalankan fungsinya sebagai lembaga dalam melindungi dan menajegkan nilai-nilai adat dan kebudayaanBali.Fungsi penting MDP sebagai struktur hukum dapat ditunjukan dengan partisipasinya dalam pembentukan produk hukum yang berorientasi pada kearifan lokal, sebagai contoh pasca diberlakukannya Undang-Undang (UU) Nomor 1 tahun 2013 tentang Lembaga Keuangan Mikro (LKM) yang mengakui LPD sebagai lembaga milik desa pakraman yang diatur berdasarkan hukum adat sebagaimana ditegaskan dalam Bab XIII pasal 39 angka (3), Majelis Desa Pakraman mengeluarkan Surat Edaran kepada seluruh bendesa/kelian adat desa pakraman-Bali. ${ }^{18}$ Surat Edaran tertanggal 6 Februari 2014 itu ditandatangani Bendesa Agung Bali, Jero Gede Suwena Putus Upadesha dan Penyarikan Agung, I Ketut Sumarta menegaskan keberadaan Lembaga Perkreditan Desa (LPD) sebagai duwe (hak milik penuh) desa pakraman berdasarkan hukum adat Bali. ${ }^{19}$ Dalam Pasal 6 Perda Provinsi Bali Nomor 4 Tahun 2012 jelas dinyatakan bahwa Ijin pendirian LPD ditetapkan dengan Keputusan Gubernur setelah mendapat rekomendasi Bupati/Walikota dan MUDP. Selanjutnya Pasal 18 juga ditegaskan bahwa Gubernur bersama-sama MUDP melakukan Pembinaan. Bertolak pada ketentuan Pasal di atas, maka jelas MUDP berperan dalam pemangunan hukum di Bali.Lebih lanjut Peran MUDP dalam pembentukan produk hukum secara sosiologis dapat dilihat dalam Tabel berikut :

18 MUDP Tegaskan Kedudukan LPD, http://www.lpdkedonganan.com/2014/02/mudp-keluarkan-se-tegaskan-lpd.html, diakses tanggal 13 Desember 2016.

19 Ibid. 
KERTHA PATRIKA

Volume 38, Nomor 3, Desember 2016

Tabel 4 : Pembahasan RUU dan Ranperda

\begin{tabular}{|l|l|}
\hline Tahun & \multicolumn{1}{|c|}{ Pembahasan (Diskusi Publik) RUU dan Ranperda } \\
\hline 2012 & $\begin{array}{l}\text { Diskusi Pembentukan Rancangan Peraturan Perundang-Undangan Perlindungan Kesatuan } \\
\text { Masyarakat Hukum Adat }\end{array}$ \\
\hline 2012 & $\begin{array}{l}\text { Diskusi Pembentukan Rancangan Peraturan Perundang-Undangan tentangLembaga } \\
\text { Keuangan Mikro. }\end{array}$ \\
\hline 2014 & Diskusi Pembentukan Rancangan Peraturan Perundang-Undangan tentangDesa. \\
\hline 2012 & $\begin{array}{l}\text { Proses Pembahasan tentang Rancangan Peraturan daerah Provinsi tentang Lembaga Perl- } \\
\text { reditan Desa. }\end{array}$ \\
\hline 2015 & $\begin{array}{l}\text { Diskusi Publik tentang Ranperda Provinsi Bali Perlindungan dan Pengelolaan Lingkungan } \\
\text { Hidup. }\end{array}$ \\
\hline
\end{tabular}

Data diolah penelusuran internet.

Partisipasi MUDP dalam proses pembentukan hukum secara teoritik dikenal dengan istilah budaya politik partisipan (participant political culture) sebagaimana dikemukakan oleh Morton R. Davies dan Vaughan A. Lewis. Konsep ini merujuk pada suatu budaya politik yang ditandai dengan adanya perilaku individu dalam masyarakat yang menganggap dirinya ataupun orang lain sebagai anggota aktif dalam kehidupan politik serta budaya politik yang mengetengahkan pelibatan publik dalam pengambilan keputusan publik. ${ }^{20}$ Secara konseptual, partisipasi dapat dikualifikasikan atas partisipasi sebagai kebijakan, partisipasi sebagai strategi, partisipasi sebagai alat komunikasi, dan partisipasi sebagai alat penyelesaian sengketa. ${ }^{21}$

\subsubsection{Kedudukan dan fungsi Majelis Desa Pakraman (MDP) dalam Penyelesaian Kasus- Kasus Adat}

Berdasarkan Purwaka Tata Cara Penyelesaian Wicara oleh MDP Bali,dinyatakan bahwa perkara adat adalah perkara yang muncul karena sengketa adat atau pelanggaran adat Bali, baik tertulis maupun tidak tertulis yang dijiwai oleh nilai-nilai agama hindu yang tidak termasuk sengketa perdata dan/ pelanggaran hukum Negara. ${ }^{22}$ Pada umumnya tata cara penyelesaian sengketa ataupun kasus adat diatur dalam Awig-Awig (aturan hukum adat desa pakraman) dan dapat diterapkan apabila kasus yang terjadi tersebut sifatnya masih intern desa pakraman. Namun demikian,sesuai dengan dinamika kehidupan bermasyarakat tidak jarang sengketa ataupun kasus adat terjadi antar desa pakraman (lintas desa pakraman). Mengingat kondisi tersebut, kemudian dibutuhkan suatu lembaga yang mempunyai kedudukan independen yaitu MDP Bali. MDP Bali yang berkedudukan sebagai lembaga/ wadah bernaungnya desa pakraman di Bali, menetapkan Keputusan Majelis Utama Desa Pakraman Bali Nomor: 002/Skep/MDP Bali/IX/2011 tentang Petunjuk Pelaksanaan dan Petunjuk Teknis Penyelesaian Wicara.

${ }^{20}$ Handoyo dan Hestu Cipto B. 2008. Prinsip-Prinsip Legal Drafting dan Desain Naskah Akademik. Yogyakarta: Penerbit Universitas Atmajaya, h.155-156.

21 Jazim Hamidi, dkk. 2008. Panduan Praktis Pembentukan Peraturan Daerah Partisipatif. Jakarta:Prestasi Pustaka Publisher, h.48-49.

22 Majelis Desa Pakraman. 2012. Purwaka Tata Cara Penyelesaian oleh Majelis Desa Pakraman (MDP) Bali. Denpasar: PenerbitMajelis Utama Desa Pakraman Bali, h. 13. 
KERTHA PATRIKA

Volume 38, Nomor 3, Desember 2016

\begin{tabular}{|l|l|l|l|}
\hline 2012 & $\begin{array}{l}\text { MUDP Bali terlibat dalam penyele- } \\
\text { saian kasus pemekaran Pangkung } \\
\text { Karung, Kecamatan Kerambitan Ka- } \\
\text { bupaten Tabanan dari Desa Pakraman } \\
\text { Bedha Kabupaten Tabanan. }\end{array}$ & $\begin{array}{l}\text { Sebagai mediator } \\
\text { (penengah) }\end{array}$ & mendamaikan \\
\hline
\end{tabular}

Sumber data diolah dari wawancara dengan prajuru MUDP Bali.

Bertolak dari data di atas maka penting dikaji secara lebih lanjut mengenai kedudukan MUDP sebagai lembaga peradilan adat dan kedudukan MUDP sebagai mediator. Dalam kasus adat anatar desa pakraman Komuning, desa pakraman Budaga dan tempek kanginan Kabupaten Klungkung, kedudukan MUDP adalah sebagai lembaga yang memberi keputusan, dalam kondisi ini MUDP berkedudukan sebagai lembaga peradilan adat. Dalam kedudukannya sebagai lembaga peradilan adat diperkuat dengan dasar Keputusan Majelis Utama Desa Pakraman Nomor 050/Kep/Psm-1/MDP Bali /III/2006 tentang Hasil-hasil Pesamuhan Agung I MDP Bali pada lampiran III butir 2: "MDP di semua tiingkatan secara berjenjang berkewenangan menyelesaikan persengketaan adat yang tidak berhasil diselesaikan di tingkat kerta desa/ prajuru desa di desa pakraman". Selain fungsi MUDP Bali menyelesaikan kasus-kasus adat baik berupa memutus dan mendamaikan, maka perlu juga disampaikan terkait dengan keputusan pesamuhan agung MUDP yang menghasilkan beberpa keputusan MUDP yang kerap kali digunakan sebagai rujukan baik bagi golongan akademisi maupun praktisi dalam menganalisis maupun dalam penyelesaian kasus (diperadilan) terkait dengan kasus-kasus yang bercirikan hukum adat bali. Adapun kumpulan Keputusan MUDP akan dituangkan dalam tabelberikut :

Tabel 7 : Kumpulan Kasus Adat

\begin{tabular}{|c|c|}
\hline No. & Keputusan \\
\hline 1. & $\begin{array}{l}\text { Keputusan Majelis Utama Desa Pakraman (MDP) Bali Nomor ; 050/Kep/Psm-1/MDP } \\
\text { I. Pali/III/2006 Tentang Hasil-Hasil Pesamuhan Agung I MDP Bali. } \\
\text { II. Pecalang } \\
\text { III. Lembaga penyelesaian Sengketa adat } \\
\text { IV. Pengelompokan penduduk desa pakraman } \\
\text { V. Peran Bendesa dalam hubungan dengan Pemindahtanganan Hak Atas Tanah di } \\
\quad \text { Wilayah Desa Pakraman. } \\
\text { VI. Batas Desa } \\
\text { VII. Investasi Di Desa Pakraman. }\end{array}$ \\
\hline 2. & $\begin{array}{l}\text { Keputusan Majelis Utama Desa Pakraman (MDP) Bali Nomor ; 050/Kep/Psm-1/MDP } \\
\text { Bali/III/2006 Tentang Hasil-Hasil Pesamuhan Agung I MDP Bali (Pernyataan Sikap } \\
\text { MDP Bali TErhadap RUU Antipornografi dan Pornoaksi). }\end{array}$ \\
\hline
\end{tabular}




\begin{tabular}{|c|c|}
\hline 3. & $\begin{array}{l}\text { Keputusan Majelis Utama Desa Pakraman (MDP) Bali Nomor ; 01/Kep/Psm-1/MDP } \\
\text { Bali/IX/2007 Tentang Hasil-Hasil Pesamuhan Agung II MDP Bali . } \\
\text { I. Keputusan Dan Rekomendasi Bidang Parahyangan } \\
\text { II. Keputusan Dan Rekomendasi Bidang Pawongan ( terkait dengan penjatuhan } \\
\text { Pamidanda/sanksi adat) } \\
\text { III. Keputusan Dan Rekomendasi Bidang Palemahan (terkait dengan Invesutasi di } \\
\text { desa pakraman. } \\
\text { IV. Keputusan Dan Rekomendasi Bidang Pelembagaan (terkait dengan kedudukan } \\
\text { kelembaag MUDP). }\end{array}$ \\
\hline 4. & $\begin{array}{l}\text { Keputusan Majelis Utama Desa Pakraman (MDP) Bali Nomor ; 01/Kep/Psm-1/MDP } \\
\text { Bali/IX/2007 Tentang Hasil-Hasil Pesamuhan Agung II MDP Bali . } \\
\text { I. Keputusan Dan Rekomendasi Bidang Parahyangan } \\
\text { II. Keputusan Dan Rekomendasi Bidang Pawongan ( terkait dengan penjatuhan } \\
\text { Pamidanda/sanksi adat) } \\
\text { III. Keputusan Dan Rekomendasi Bidang Palemahan (terkait dengan Invesutasi di } \\
\text { desa pakraman. } \\
\text { IV. Keputusan Dan Rekomendasi Bidang Pelembagaan (terkait dengan kedudukan } \\
\text { kelembaag MUDP) } \\
\text { Keputusan Majelis Utama Desa Pakraman (MDP) Bali Nomor ; 003/Kep/Psm-A3/ } \\
\text { MUDP Bali/X/2010 Tentang Hasil-Hasil Pesamuhan Agung III MUDP Provinsi Bali . } \\
\text { I. Bidang Program Unggulan Mahelis Desa Pakraman (MDP) Bali. } \\
\text { II. Bidang Kelembagaan } \\
\text { a. Tata hubungan Antara Desa Pakraman dengan desa dinas di Bali. } \\
\text { b. Tata Hubungan Desa Pakraman dengan Tamiu dan/atau lembaga lain. } \\
\text { c. Desa pakraman dengan desa pakraman yang bermasalah. } \\
\text { d. Penguatan kedudukan Lembaga Perkreditan Desa (LPD). } \\
\text { III. Bidang hukum adat } \\
\text { a. Kedudukan wanita Bali dalam keluarga dan Pewarisan. } \\
\text { b. Pelaksanaan perkawinan dan perceraian. } \\
\text { c. Krama Tamiu dan Tamiu yang berdomisili dan membuka Usaha di desa pak- } \\
\text { Iv. Pengenaan sanksi adat Kasepekang dan Kanohrayang. }\end{array}$ \\
\hline 5. & $\begin{array}{l}\text { Keputusan Majelis Utama Desa Pakraman (MDP) Bali Nomor : 01/Kep/Psm-4/MDP } \\
\text { Bali/XI/2012 Tentang Hasil-Hasil Pesamuhan Agung IV MDP Bali . } \\
\text { I. Bidang Kelembagaan } \\
\text { a. Awig-awig LPD } \\
\text { b. Tata cara pemilihan Bendesa/Prajuru } \\
\text { II. Bidang Palemahan } \\
\text { a. Tata cara Investasi Di Desa } \\
\text { b. Penetapan Desa Pakraman Baru } \\
\text { III. Bidang Hukum Adat } \\
\text { a. Wates Desa (Batas Desa) } \\
\text { b. Upacara menjelang PEnguburan Jenasah bagi orang yang salah pati, ulah pati dan } \\
\text { c. Porban HIV/AIDS. }\end{array}$ \\
\hline
\end{tabular}




\begin{tabular}{|l|l|}
\hline 6. & Keputusan Majelis Utama Desa Pakraman (MDP) Bali Nomor : 01/Kep/Psm-5/MDP \\
& Bali/XII/2013 Tentang Hasil-Hasil Pesamuhan Agung V MDP Bali. \\
& I. $\quad$ Keberadaan LPD Pasca UU Nomor 1 Tahun 2013 tentang Lembaga Keuangan \\
& Mikro. \\
& II. $\quad$ Laporan pertangungjwaban Dana Hibah/ Bantuan sosial. \\
\hline
\end{tabular}

Sumber : Data diolah dari beberapa buku putusan MUDP Bali.

Dengan demikian ada dua (2) hal yang menjadi kewenangan MUDP dalam penyelesaian kasus-kasus adat yaitu berwenang dalam memutus dan mendamaikan. Pertama, dalam kedudukan dan fungsi sebagai Pemutus (peran sebagai lembaga peradilan adat), MUDP berkedudukan sebagai Sabha Kerta (HakimPerdamaian Desa). Mengenai tata cara pelaksanaanperadilan adat yang dilakukan oleh MUDP telah diatur dalam ketentuan Keputusan Majelis Utama Desa Pakraman Bali Nomor 002/Skep/ MDP Bali/IX/2011 tentang petunjuk pelaksana dan petunjuk teknis (juklak-juknis) dalam penyelesaian wicara (kasus adat). Lebih lanjut dalam Keputusan Majelis Utama Desa Pakraman Bali Nomor 002/ Skep/MDP Bali/IX/2011 juga dijelaskan point-point dalam penyelesaian wicara (kasusu) yang diserahkan ke MUDP yaitu :

1. Keputusan akan diambil dalam siding Sabha Kerta MMDP dan/atau MUDP berdasrkan berkas Wicara, temuan, serta rekomendasi Panureksa MMDP dan/atau MUDP.

2. Para pihak yang maawicara tidak memungkinkan untuk melakukan tawar menawar guna menemukan penyelesaian terbaik yang sesuai dengan rasa keadilan masing-masing.

3. Apabila para pihak yang mawicara keberatan atas keputusan MMDP dapat melakukan upaya hukum dengan mengajukan keberatan kepada MUDP selambat-lambatnya 21 hari sejak tanggal keputusan MMDP diterima oleh pihak yang mawicara.

4. Apabila dalam tersebut tenggang waktu belum ada pernyataan keberatan terhadap MMDP yang diajukan secara tertulis, maka keputusan MMDP memiliki kekuatan hukum tetap. Sepanjang belum ada keputusan lain dari MUDP maka keputusan MMDP tetap berlaku.

5. Keputusan Sabha Kerta MUDP bersifat final dan mengikat pihak-pihak yang mawicara sehingga secara yuridis dan moral berlaku sebagai aturan hukum bagi pihak-pihak yang mewicara. Dengan adanya keputusan final MUDP, maka masalah adat dinyatakan telah selesai.

6. Keputusan Sabha Kerta MUDP yang sudah berkekuatan hukum tetap menjadi rujkan bagi wicara sejenis yang muncul di kemudian hari.

Kedua, dalam kedudukan dan fungsi MUDP sebagai mediator, maka tujuan utamanya adalah mendamaikan pihak-pihak yang bersengketa. Merujuk teorinya M Koesnoe tentang ajaran menyelesaikan yang mempunyai makna bahwa sengketa adat diseslesaikan dengan perundingan dan mediasi. MUDP dalam kapasistasnya sebagai medioator dalam menyelesaikan kasus maka ada point-point yang harus ditaati oleh para pihak yang bersengketa. Mendasarkan pada Pasal 16 Perda No.3 Tahun 2003 menyatakan bahwa MDP berwenang menjadi penengah dalam penyelesian sengketa adat dan mendasarkan Keputusan Majelis Utama Desa Pakraman Bali Nomor 002/Skep/MDP Bali/IX/2011 juga telah diatur tentang beberpa ketentuan terkait dengan penyelesaian dengan mediasi yaitu :

1. Para pihak yang mawicara masih dimungkinkan untuk menemukan penyelesaian terbaik yang sesuai dengan rasa keadilan masing-masing. 


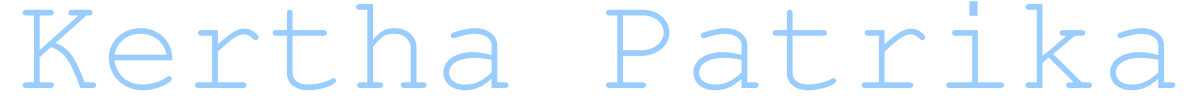

\section{KERTHA PATRIKA}

Volume 38, Nomor 3, Desember 2016

2. Saran kepada Pemerintah Provinsi Bali yaitu untuk sesegera mungkin merevisi Perda 3 Tahun 2001 karena muatan materi Perda 3 tahun 2001 sudah tidak relevan dengan perkembangan jaman terutama berkaitan dengan elaborasi nilai hukum adat dengan globalisasi.

3. Saran kepada MDP Bali, agar mengumumkan melalui media baik media elektronik maupun media massa terkait dengan program-program dan bentuk-bentuk kegiatan apa saja yang telah dilaksanakan setiap tahunnya, terkait dengan pelestarian, penguatan, pemberdayaan hukum adat dan budaya Bali.

\section{DAFTAR PUSTAKA}

\section{Buku}

Gaffar, Janedjri M. 2013. Demokrasi dan Pemilu Di Indonesia. Jakarta: Penerbit Konstitusi Press khasanah peradaban hukum \& konstitusi.

Hamidi, Jazim, dkk. 2008. Panduan Praktis Pembentukan Peraturan Daerah Partisipatif. Jakarta: Prestasi Pustaka Publisher.

Hamidi, Jazim. 2008. Panduan Praktis Pembentukan Peraturan Daerah Partisipatif. Jakarta: Penerbit Prestasi Pustaka Publiher.

Handoyo dan Cipto, Hestu B. 2008. Prinsip-Prinsip Legal Drafting dan Desain Naskah Akademik. Yogyakarta: Penerbit Universitas Atmajaya.

Koesnoe, H. Moh. 1992. Hukum Adat sebagai suatu Model Hukum. Bandung: Penerbit Bandar Maju.

Majelis Desa Pakraman. 2012. Purwaka Tata Cara Penyelesaian oleh Majelis Desa Pakraman (MDP) Bali. Denpasar: Penerbit Majelis Utama Desa Pakraman Bali. 2014. Kompilasi Hasil-Hasil Pesamuhan Agung. Denpasar: Penerbit Majelis Utama Desa Pakraman.

Rasjidi, H. Lili. 2008, "Pembangunan Sistem Hukum Dalam Rangka Pembinaan Hukum Nasional" dalam Butir-Butir Pemikiran Tentang Hukum Memperingati 70 Tahun Prof. Dr. B Arief Sidharta., SH., Bandung: Refika Aditama.

Salman, HR. Otje dan Susanto, Anthon F. 2004. Beberapa Aspek Sosiologi Hukum. Bandung: Penerbit Alumni.

Soemadiningrat, Otje Salman. 2002. Rekonseptualisasi Hukum Adat Kontenporer. Bandung: Penerbit Alumni.

Wiranata, A.B. 2005. Hukum Adat Indonesia Perkembangannya dari Masa ke Masa. Bandung: Citra Aditya Bakti. 


\section{Jurnal}

Nurjaya, I Nyoman, Memahami Kedudukan dan Kapasitas Hukum Adat Dalam Politik Pembangunan Hukum Nasional, Perspektif, 2011,Vol. XVI No. 4.

Novita, Ni Ketut Sari, Sulistyarini, Rachmi, dan Ratih Dheviana Puru HT, Pelaksanaan Keputusan Pesamuhan Agung III Majelis Utama Desa Pakraman (MUDP) Terkait Kedudukan Perempuan Hindu Bali Sebagai Ahli Waris (Studi di Desa Pakraman Batubulan Kangin, Kecamatan Sukawati, Kabupaten Gianyar, Bali), Jurnal Hukum, 2015, Universitas Brawijaya,http://hukum. studentjournal.ub.ac.id/index.php/hukum/article/view/915/906

\section{Internet}

Pembangunan Sistem Hukum Nasional Indonesia, https://bardanawawi.wordpress. $\operatorname{com} / 2009 / 12 / 24 / 38 /$.

Hendra Wahanu Prabandani, Pembangunan Hukum BerbasisKearifan Lokal, http://birohukum.bappenas.go.id/data/data_artikel_jdih/PEMBANGUNAN\%20HUKUM\%20BERBASIS\%20KEARIFAN\%20LOKAL.pdf.

MUDP Tegaskan KedudukanLPD, http://www.lpdkedonganan.com/2014/02/mudp-keluarkan-se-tegaskan-lpd.html. 